\title{
Are Institutional Investors Concerned about Corporate Social Responsibility Risk?
}

\author{
Yi Chen \\ School of Management, Jinan University, Guangzhou, China \\ Email: Messiah_chenyi@163.com
}

How to cite this paper: Chen, Y. (2020). Are Institutional Investors Concerned about Corporate Social Responsibility Risk? Open Journal of Social Sciences, 8, 427-454. https://doi.org/10.4236/jss.2020.83037

Received: February 17, 2020

Accepted: March 24, 2020

Published: March 27, 2020

Copyright $\odot 2020$ by author(s) and Scientific Research Publishing Inc. This work is licensed under the Creative Commons Attribution International License (CC BY 4.0).

http://creativecommons.org/licenses/by/4.0/

\begin{abstract}
This paper uses the data of the RepRisk database to construct corporate social responsibility risk indicators (CSR Risk), and examines the relationship between corporate social responsibility risk and institutional holdings. The study found that there is a significant negative correlation between the institutional investor's shareholding and corporate social responsibility risk, and the above relationship is even more pronounced in regions with a higher degree of marketization, state-owned listed companies, and companies with better operating performance. In further analysis, this article finds that corporate social responsibility risk will negatively affect earnings sustainability and corporate value, which means that investors investing in companies with higher social responsibility risk will reduce the investment value.
\end{abstract}

\section{Keywords}

CSR Risk, Institutional Investor, Marketization, Property Right, Business Performance

\section{Introduction}

As an era of green, circular, and low-carbon development, the sustainable development concept of "Lucid waters and lush mountains are invaluable assets" is deeply rooted in the hearts and minds of all sectors of society. Social responsibility incidents (i.e. scandals) will bring indelible losses to companies (Skinner and Srinivasan, 2012). Scandals such as the Sanlu Poisonous Milk Powder, the Deepwater Horizon oil spill, the Volkswagen's “emissions" incident, and the recent Changchun Changsheng vaccine scandal have proven this (Xie et al., 2017). These endless corporate vicious accidents and frauds have entered the public's "vision" through media reports, making people realize that "Social Responsibility" is not a word that is far from the sky and nothingness, but an objective fact 
that is imminent and involves their own interests.

Under the tragic baptism of vicious social responsibility incidents, the topic of corporate social responsibility was once again pushed to the forefront of public opinion and became the focus of attention (He et al., 2018). The government has also issued a series of laws and regulations to promote the implementation of corporate social responsibility. President Xi emphasized in his speech in April 2018: "Enterprise development must adhere to the unification of economic and social benefits, and better shoulder social and moral responsibilities". As a growing investment group in the capital market, institutional investors will inevitably pay attention to corporate social responsibility and use it as a reference standard for making investment decisions (Dhaliwal et al., 2011).

As the saying goes, "For evil news rides fast, while good news baits later". According to the "negative bias" principle, individuals tend to be more biased towards negative news than positive news (Bednar et al., 2013), because negative news contribute more to final impressions than positive news (Rozin and Royzman, 2001; Tetlock, 2007). Most studies believe that corporate social responsibility may not immediately lead to an increase in corporate reputation and performance. However, once bad social responsibility behaviors occur, companies will face huge risks. But in the current theory and practice, we still have the following questions to answer: Do institutional investors in China consider corporate social responsibility risk when making decisions? The impact of corporate social responsibility risk on institutional shareholdings is more significant in which types of enterprises? Why does social responsibility risk affect institutional investor holdings? By finding the answers to the above questions, we can gain a deeper understanding of the investment decisions of institutional investors.

In order to answer the above questions, this paper obtained the social responsibility risk data of listed companies in China from 2007 to 2016 through the RepRisk database, and examined the impact of corporate social responsibility risk on the investment behavior of institutional investors in China. The study found that there is a significant negative correlation between the institutional investor's shareholding and corporate social responsibility risk, and the above relationship is even more pronounced in regions with a higher degree of marketization, state-owned listed companies, and companies with better operating performance. In further analysis, this article finds that corporate social responsibility risk will negatively affect earnings sustainability and corporate value, which means that investors investing in companies with higher social responsibility risk will reduce the investment value.

Our research may have the following contributions. First, in the study of corporate social responsibility and institutional investors, the discussion is more about the positive effects of corporate social responsibility, but this article that based on the negative behaviors of corporate social responsibility has enriched relevant research literature. Second, in many studies on the relationship between corporate social responsibility and risk, the volatility of stock returns is generally 
used to measure the risk of the company (Luo and Bhattacharya, 2009), but this study uses the RepRisk database to quantify the performance of corporate social responsibility and provides a social responsibility risk assessment standard. Third, considering the different impacts of marketization, the nature of property rights, and business performance on the relationship between corporate social responsibility risk and institutional shareholding, and further studying the influence path of social responsibility risk on institutional investors' shareholding behavior, it is a useful supplement to the relevant literature (Cox and Wicks, 2011).

The remainder of the paper is organized as follows. First, we study the literature on CSP and institutional investor holdings. Second, we propose research hypotheses. Third, we explain our study design, including sample selection, data sources, variable selection, and study models. Fourth, we conduct empirical tests and result analysis. Finally, we present our findings and limitations.

\section{Literature Review}

The investment decisions of institutional investors have been the research hotspots of scholars. By combing related literature, foreign scholars have found that transaction costs, information asymmetry, net loss costs and corporate performance significantly affect the investment behavior of institutional investors in Western markets (Gompers and Metrick, 2001; Kang, 1997; Dahlquist and Robertsson, 2001). Gompers and Metrick (2001) found that the larger the company's scale, the higher the possibility of institutional investors to invest, and the higher the stock price of the company. In addition to the influence of the company's micro-level characteristics, the distance between investors and the company, the homogeneity of the cultural background of the company's executives, and language habits also affect the behavior of institutional investors (Grinblatt and Keloharju, 2001). In addition, most foreign scholars believe that institutional investors have strong value selection capabilities (Cornett et al., 2007), so corporate performance will significantly affect institutional investors' holdings (Cornett et al., 2007; Li et al., 2006). In a comparative study of the choice of domestic and foreign capital markets for investors, most studies found that investors are more inclined to invest in domestic capital markets and certain foreign capital markets (Cooper and Kaplanis, 1994; Chan et al., 2005), the investment bias of this type of regional selection is mainly based on considerations such as the degree of economic development, the degree of capital market development, the level of tax rates, and the cost of net losses (Chan et al., 2005).

The results of research on the investment decisions of institutional investors in China's capital market show that the investment behavior of institutional investors in China is affected by the macro environment and micro characteristics. Research by Lin et al. (2013) shows that the size, growth ability, profitability, and equity concentration of an enterprise affect the holding behavior of institutional 
investors. In addition, the company's geographical location and regional political intervention can also affect institutional investors Investor strategy (Song et al., 2012). Tian et al. (2012) found that institutional investors will choose stocks with lower net loss costs. At the same time, the economic development level and industry characteristics of the stock location will also affect the investment behavior of institutional investors in China. Chen et al. (2007) and Yang (2008) believe that institutional investors are inclined to long-term and valued investment behavior, and they will make investment choices based on the company's past performance. In addition, institutional investors also favor investing in companies that are financially sound and effective (Shi and Wang, 2014). In summary, domestic and foreign research on the influencing factors of institutional investor investment behavior is mainly concerned with economic or financial factors, such as macroeconomic policies, enterprise size, operating performance, profitability, growth, and transaction costs.

Scholars at home and abroad have also studied the impact of non-financial factors on institutional investors, such as corporate social responsibility (Clarkson et al., 2010). By sorting out relevant literature, foreign scholars have already begun to explore the relationship between corporate social responsibility and institutional investors. Since the early 1990s, many foreign individual and institutional investors have begun to consider the "socially responsible" principle when making investment decisions (Hoq et al., 2010). Coffey and Fryxell (1991) first opened up the corporate social responsibility perspective of institutional investors' shareholding preferences, conducted empirical research from the perspective of corporate charitable donations, and proposed that institutional investors have no clear relationship with charitable donations. Graves and Waddock (1994) questioned its research design, improved the research sample and model design on this basis, found that there is a positive correlation between institutional investors' stock preferences and social responsibility, and showed that this preference is partly due to the long-term performance of the investment. That is, in the long run, corporate social responsibility adds value to the organization and in turn attracts institutional investors (Clarkson et al., 2010; Petersen and Vredenburg, 2009; Cormier et al., 2005). The findings of Graves and Waddock (1994) were supported by Cox et al. (2004). On this basis, Petersen and Vredenburg (2009) explored the attitude of institutional investors to corporate social responsibility, and the results show that institutional investors do not specifically consider corporate ethics when making investment decisions, but rather pay more attention to the economic value of social responsibility. This is sufficient to show that corporate social responsibility not only improves the company's financial performance, but also brings positive responses from institutional investors. At the same time, on the basis of exploring whether social responsibility has become an influential factor for institutional investors to make investment decisions, Petersen and Vredenburg (2009) further proposed that social responsibility activities determine whether institutional investors should invest or not. This conclusion is the 
same as the empirical results of Arora and Dharwadkar (2011). In addition, the research results of scholars such as Becchetti et al. (2012), Kangarluie and Bayazidi (2011), also show that institutional investors are more inclined to invest in companies with better corporate social responsibility performance.

There are few domestic studies on the impact of corporate social responsibility on institutional investor holdings. Li and $\mathrm{Lu}$ (2015) explored the relationship between environmental performance and the institutional investor's shareholding for the environmental dimension of corporate social responsibility, and found that institutional investors tend to invest in companies with better environmental performance because the government supports corporate bank loans and income tax incentives to encourage their environmental performance to improve. Mao et al. (2012) examined the relationship between the shareholding preferences of six types of institutional investors and corporate social performance in China, and found that the relationship between various types of institutional shareholdings and social responsibility is quite different. Among them, fund investor shareholding preferences and social responsibility are significantly positive. Wang et al. (2011) further analyzed the ways in which corporate social responsibility affects institutional investor shareholdings, and proposed a transmission mechanism of "corporate social responsibility-corporate performanceinstitutional shareholding preferences".

In summary, there may be some room for improvement: First, the current literature focuses on the impact of macroeconomic environment, industry characteristics, corporate characteristics, corporate social responsibility and other factors on institutional investor investment behavior, but compared with foreign countries, there are still few literatures on the impact of corporate social responsibility on institutional investors in China, and mainly focuses on the positive effects brought by corporate social responsibility, ignoring corporate social responsibility risk caused by the negative behaviors. Second, domestic literature is more about exploring the relationship between corporate social responsibility and institutional investors, and less examining the different impacts of marketization, property rights, and business performance on their relationships. In addition, few scholars have studied the impact of social responsibility and its risks on institutional investors' shareholding behavior. Third, most of the domestic literature has explored the impact of media reports on corporate social responsibility negative behaviors, but few have explored the risks of corporate social responsibility brought by such negative reports.

\section{Research Hypothesis}

In this study, we define social responsibility risk as the risk of loss due to negative media coverage of a company's social responsibility. We explore the relationship between corporate social responsibility risk and institutional holdings through corporate social responsibility risk indicators in the RepRisk database. We first conduct a regression analysis of corporate social responsibility risk and 
the institutional investor's shareholding. Since CSR Risk will reduce the value of the company, we speculate that there is a negative correlation between CSR Risk and institutional investors. Secondly, according to the degree of regional marketization, differences in property rights, and corporate performance to study the differences in impact, we believe that the negative correlation between CSR Risk and institutional investors will not change.

We used three regression models to test the relationship between CSR Risk and the institutional investor's shareholding behavior, which are mixed regression model, fixed-effect model, and random effect model. The F-test was used to select the fixed-effect model in the mixed model and the fixed-effect model. The BP test was used to select the random-effect model in the mixed model and the random-effect model. Finally, the Hausman test was used in the fixed-effect model and the random-effect model. Based on the test results, we decided to use a fixed-effect model. In order to alleviate endogenous problems, the empirical tests of all models in this paper use a two-way panel fixed effect (FE model) that controls the individual effect and annual effect of the company to alleviate the problem of missing variables of the company that does not change over time. And the cluster method is used to adjust the standard error according to the company code.

\subsection{CSR Risk and Institutional Investors}

Institutional investors consider corporate social responsibility information as an important consideration when deciding to continue holding or selling their shares (Hoq et al., 2010). Companies with good corporate social responsibility performance not only have higher stock returns (Edmans, 2011), lower market risk ( $\mathrm{Ma}$ and Li, 2015), and higher corporate value (Lev et al., 2010), but also attract more attention from investors and analysts (Dhaliwal et al., 2011). However, once a company faces social responsibility risk, it will send a signal to the outside world that its management capabilities are not strong, which will not only damage the company's reputation and incur administrative penalties (Core et al., 2008; Christensen, 2015; Karpoff et al., 2005; Liu et al., 2013, 2014), but also damage the performance of the company and reduce the market value of the company (Karpoff et al., 2005; Li et al., 2006; Shen et al., 2012).

Institutional investors are generally considered to have professional advantages and information advantages (Boehmer and Kelley, 2009). They can obtain information on corporate social responsibility to make optimal investment decisions (Wang et al., 2011). They can also perceive the damage caused by CSR risk, such as the impact on the sustainable development of the company, the decline in short-term stock prices, and the damage to long-term value. Therefore, due to the consideration of long-term benefits and self-interest, institutional investors will reduce investment in companies with high social responsibility risk in order to reduce investment risks (Petersen and Vredenburg, 2009). Based on this, we predict this in our first hypothesis. 
Hypothesis 1: Institutional investors hate corporate social responsibility risk, that is, the proportion of institutional investor's shareholding is negatively related to corporate social responsibility risk.

\subsection{Degree of Marketization, CSR Risk and Institutional Investors}

Generally speaking, in regions with a high degree of marketization, the level of legalization and economic development are usually high, institutional investors also tend to prefer investing in Developed regions. In regions where the marketization process is relatively low, an imperfect institutional system will affect the protection of investors' voting rights and the right to know, thereby restricting the motivation and enthusiasm of institutional investors. Therefore, in areas with a high degree of marketization, if the performance of the company's social responsibility is poor, the company will face stricter penalties by the regulatory agency and more severe criticism from the public (Liu et al., 2013, 2014), which will damage the company's value and affect investors' willingness to invest.

In addition, due to the asymmetry of information between the media and the public, the media may enter into a private transaction with the company and gain benefits by hiding the negative information. This is the rent-seeking behavior of the media (Zheng, 2007). For companies, in order to prevent negative information from causing fluctuations in the company's stock price, companies often also "collusion" with the media to maintain a positive image. Regions with lower marketization levels tend to have relatively low levels of rule of law and regulatory power, The possibility of companies intervening in the media is greatly enhanced when they encounter negative media reports, and through "private" transactions, the media are encouraged to report according to their wishes (Gurun and Butler, 2012). However, in regions with a high degree of marketization, a good institutional environment provides important guarantees for external supervision, helps the media to perform public opinion supervision and information transmission functions, and enables institutional investors to more objectively assess corporate social responsibility risk for investment decision making. Therefore, we predict this in our second hypothesis.

Hypothesis 2: Compared with regions with low levels of marketization, the negative impact of corporate social responsibility risk on institutional investor holdings is more significant in regions with higher levels of marketization.

\subsection{Property Right, CSR Risk and Institutional Investors}

The difference in the nature of property rights has been a hot topic of research. The impact of corporate social responsibility risk on institutional investors may have different performances in different natures of property rights. First of all, compared with non-state-owned enterprises, state-owned enterprises should not only undertake social responsibilities such as ecological environmental protection, employment pressure relief, and public welfare donations, but also need to 
play a role in maintaining social stability. Therefore, when state-owned enterprises are under pressure from negative public opinion due to social responsibility issues, in order to avoid social panic and instability, the government often intervenes in the media and urges the media to report according to the government's wishes (Gurun and Butler, 2012), which will alleviate the impact of social responsibility risk on state-owned enterprises and maintain social stability.

Secondly, with the introduction of green policies such as "green credit", "green insurance" and "green securities", bank loans and financing, tax incentives, and fiscal subsidies for enterprises largely depend on their social responsibility performance ( $\mathrm{Li}$ and $\mathrm{Lu}, 2015$ ). State-owned enterprises and the government have inherently close ties, and generally receive more resource support than nonstate-owned enterprises. When faced with social responsibility risk, close government-enterprise relations provide a "protective barrier" for state-owned enterprises, making the value loss suffered by state-owned enterprises much smaller than non-state-owned enterprises. In contrast, non-state-owned enterprises generally receive less direct government investment, and once non-state-owned enterprises face social responsibility risk, it will damage the confidence of the public, financial institutions and governments in enterprises, and increase the difficulty and cost of corporate financing (Cheng et al., 2014; Ye et al., 2010), thus affecting the willingness of institutional investors to invest. Based on this, we predict this in our third hypothesis.

Hypothesis 3: Compared with state-owned enterprises, the negative impact of corporate social responsibility risk on institutional investor holdings is more serious in non-state-owned enterprises.

\subsection{Business Performance, CSR Risk and Institutional Investors}

Relevant research shows that the better the company's performance, the higher the probability that institutional investors will invest (Gompers and Metrick, 2001; Li et al., 2006; Cornett et al., 2007; Lin et al., 2013; Chen et al., 2007; Yang, 2008; Shi and Wang, 2014). Generally speaking, listed companies with good financial performance or growth have more investment opportunities and their investment decisions will be more valuable. Institutional investors usually also invest in companies with better financial performance, because the cash flow generated by their investment activities has a higher market value and higher investment quality (Cornett et al., 2007; Tian et al., 2012). However, if a listed company faces high social responsibility risk due to social responsibility issues, institutional investors may choose to reduce or abandon their investment in the company due to investment risk considerations. Conversely, companies with poor financial performance often lack valuable investment opportunities and are generally not "favored" by institutional investors. The lack of attention has avoided the impact of corporate social responsibility risk on institutional holdings. 
In addition, according to political cost theory, companies with higher profitability and greater social impact are more likely to receive higher attention, and people from all walks of life will express higher expectations for their social responsibility performance (Shen, 2007). Based on this, companies with higher profitability will also face greater pressure on public legitimacy. Once these companies encounter social responsibility risk, they will be subject to more media reports and public condemnation, which will expose companies to reputational risks (Core et al. al., 2008; Christensen, 2015), affecting investors' willingness to invest. At the same time, media reports can form a "eye-holding effect" that makes the reported company the focus of public opinion, and the reputational impact reduces the social recognition of enterprises (Zavyalova et al., 2012), making it difficult for enterprises to obtain (Cheng et al., 2014), ultimately affecting the long-term value of the company (Byun and Oh, 2018). Based on this, we predict this in our fourth hypothesis.

Hypothesis 4: Compared with listed companies with poor financial performance, corporate social responsibility risk has a more serious negative impact on institutional investors in companies with better financial performance.

\section{Research Design}

\subsection{Sample Selection and Data Sources}

This article selects A-share listed companies in Shanghai and Shenzhen in 20072016 as the research sample. At the same time, the sample is processed as follows: 1) considering the specificity of capital results of financial and insurance companies, this article excludes the financial and insurance industry; 2) removes samples with missing data; 3) removes ST and * ST samples; 4) Excluding the sample of insolvency (asset-liability ratio > 1), 3569 observations were finally obtained. In order to control the influence of extreme values, this paper performs a Wionsorize treatment of all continuous variables with upper and lower $1 \%$ quantiles.

The institutional ownership data and annual stock turnover data used in this article are from the WIND database. The marketization index for each region is derived from the "China's Marketization Index Report by Province", other financial data of the company comes from the CSMAR database, and social responsibility risk data comes from the RepRisk database, an authoritative thirdparty rating agency for social responsibility risk. The RepRisk database is rooted in the media's negative sentiment towards corporate environmental, social and governance issues (ESG issues, as shown in Table 1), and is the main source of corporate social performance information (Luo et al., 2015).

\subsection{Research Model}

In order to test the impact of corporate social responsibility risk on institutional investors, the following models are constructed for testing. (See Table 2 for 
Table 1. RepRisk scope of ESG issue.

\begin{tabular}{llll}
\hline Environmental Issues & Social Issues & & Governance Issues \\
\cline { 2 - 4 } & Community Relations & Employee Relations & \\
\hline Global Pollution (including Climate Change) & Human Rights Abuses & Forced Labor & $\begin{array}{l}\text { Corruption, Bribery, Extortion, } \\
\text { Money Laundering }\end{array}$ \\
Local Pollution & & & Executive Compensation \\
Impacts on the Ecosystems and Landscapes & Local Participation issues & Violation of employee rights & Misleading Communication \\
Overuse and Wasting of Resources & Social Discrimination & Employment Discrimination & Fraud \\
Waste Issues & & Health and Safety Issues & Tax Evasion \\
Animal Mistreatmengt & Poor Employment Conditions & Anti-competitive Practices \\
Cross-cutting issues & & & \\
Controversial Products and Services/Product-related health and environmental issues/Violation of International Standards/Violation of National \\
Legislation/Supply Chain Issues
\end{tabular}

Table 2. Definition of main variables.

\begin{tabular}{|c|c|c|}
\hline Variable Type & Variable Symbol & Definition \\
\hline Dependent variable & INS & Institutional investor's shareholding ratio, data from WIND database \\
\hline Independent variable & CSR Risk & Corporate social responsibility risk, data from RepRisk database \\
\hline \multirow[t]{19}{*}{ Control variable } & SIZE & Company size, natural logarithm of total assets \\
\hline & LEV & Financial leverage, liabilities divided by assets \\
\hline & State & $\begin{array}{l}\text { Dummy variable, when the actual controller of the enterprise is set to } 1 \text { for the state-owned unit, } \\
\text { otherwise } 0\end{array}$ \\
\hline & ROA & Return on total assets, annual net profit divided by total assets at the end of the year \\
\hline & Growth & $\begin{array}{l}\text { Operating income growth rate, the current operating income minus the operating income of the } \\
\text { previous period, and then divided by the operating income of the previous period }\end{array}$ \\
\hline & TRSHARE & Natural logarithm of the number of shares outstanding at the end of the year \\
\hline & TOP & Equity concentration, the sum of the company's largest shareholder's shareholding ratio \\
\hline & TAMVB & Book value ratio, total assets divided by market value \\
\hline & BPS & Net assets per share, net assets divided by the number of ordinary shares at the end of the period \\
\hline & Mortgage & Fixed assets ratio, fixed assets divided by total assets \\
\hline & VOL & Annual turnover of corporate stocks \\
\hline & EXCP & Executive compensation, the natural logarithm of the top 3 executive compensation \\
\hline & IDB & $\begin{array}{l}\text { Independent director ratio, the number of independent directors divided by the number of } \\
\text { directors }\end{array}$ \\
\hline & GCFO & Net flow growth rate from operating activities \\
\hline & SC & Selling expenses as a percentage of assets, selling expenses divided by total assets \\
\hline & JNN & $\begin{array}{l}\text { Shareholding ratio of the Supervisory Board, divided by the total number of shares held by the } \\
\text { Supervisory Board }\end{array}$ \\
\hline & ROWC & Working capital turnover, operating income divided by average working capital \\
\hline & Market & Marketization index, the data comes from "China's Marketization Index Report by Province" \\
\hline & WCLRat & Working capital to borrowing ratio, working capital divided by total borrowings \\
\hline
\end{tabular}


variable definitions)

$$
\begin{aligned}
\text { INS }= & \alpha_{0}+\alpha_{1} \text { CSR Risk }+\alpha_{2} \text { SIZE }+\alpha_{3} \mathrm{LEV}+\alpha_{4} \text { State }+\alpha_{5} \text { ROA } \\
& +\alpha_{6} \text { Growth }+\alpha_{7} \text { TOP }+\alpha_{8} \mathrm{BPS}+\alpha_{9} \text { TRSHARE }+\alpha_{10} \text { TAMVB } \\
& +\alpha_{11} \text { Mortgage }+\alpha_{12} \mathrm{IDB}+\alpha_{13} \mathrm{SC}+\alpha_{14} \mathrm{JNN}+\alpha_{15} \mathrm{VOL} \\
& +\alpha_{16} \mathrm{GCFO}+\alpha_{17} \text { ROWC }+ \text { Stkcdeffect }+ \text { Yeareffect }+\varepsilon
\end{aligned}
$$

\section{Empirical Test and Analysis}

\subsection{Descriptive Statistics}

Table 3 is the descriptive statistics of the main variables in the research model of this paper. As can be seen from the table, the average shareholding ratio of institutional investors is $43.929 \%$. On the whole, the proportion of institutional investors in China's capital market is relatively high, which shows that with the strong support of relevant departments, China's institutional investor team has grown stronger and has become an indispensable force in China's capital market; The maximum shareholding ratio is $90.982 \%$, and the standard deviation is large (24.098), indicating that institutional investors play a leading role in some companies. The average corporate social responsibility risk is 10.01 and the me-

\begin{tabular}{|c|c|c|c|c|c|c|}
\hline variable & $\mathbf{n}$ & mean & $p 50$ & sd & $\min$ & $\max$ \\
\hline INS (\%) & 3569 & 43.929 & 45.583 & 24.098 & 0.625 & 90.982 \\
\hline CSR Risk & 3569 & 10.010 & -1 & 14.159 & -1 & 45 \\
\hline ROA & 3569 & 0.041 & 0.034 & 0.060 & -0.158 & 0.235 \\
\hline SIZE & 3569 & 22.564 & 22.480 & 1.415 & 19.452 & 26.179 \\
\hline State & 3569 & 0.614 & 1 & 0.487 & 0 & 1 \\
\hline LEV & 3569 & 0.536 & 0.554 & 0.195 & 0.087 & 0.910 \\
\hline TRSHARE & 3569 & 20.269 & 20.168 & 1.200 & 17.522 & 23.556 \\
\hline TOP & 3569 & 37.979 & 36.570 & 16.458 & 8.400 & 78.550 \\
\hline BPS & 3569 & 4.071 & 3.619 & 2.450 & 0.400 & 14.067 \\
\hline TAMVB & 3569 & 0.587 & 0.560 & 0.265 & 0.106 & 1.138 \\
\hline Mortgage & 3569 & 0.219 & 0.168 & 0.190 & 0 & 0.750 \\
\hline IDB & 3569 & 0.373 & 0.333 & 0.057 & 0.300 & 0.571 \\
\hline GCFO & 3569 & 0.002 & -0.242 & 5.473 & -20.007 & 34.998 \\
\hline SC & 3569 & 0.035 & 0.013 & 0.059 & 0 & 0.307 \\
\hline VOL & 3569 & 2.404 & 1.931 & 1.731 & 0.200 & 8.450 \\
\hline JNN & 3569 & 0.001 & 0 & 0.004 & 0 & 0.034 \\
\hline Growth & 3569 & 0.165 & 0.083 & 0.613 & -0.812 & 4.722 \\
\hline ROWC & 3569 & 3.589 & 1.717 & 32.314 & -149.660 & 180.728 \\
\hline
\end{tabular}
dian is -1 (indicating that the enterprise has not experienced ESG problems), and the overall level of corporate social responsibility risk in China is not high at

Table 3. Descriptive statistics of variables. 
this stage, indicating that Chinese enterprises are less exposed to social responsibility risk issues. The maximum value of corporate social responsibility risk is 45 , the minimum value is -1 , and the standard deviation is large, indicating that the social responsibility risk of Chinese enterprises is very different.

\subsection{Regression Analysis}

\subsubsection{CSR Risk and Institutional Investors}

In order to test the relationship between corporate social responsibility risk and institutional investor shareholding, I conducted regression analysis according to model (1), and the results are shown in Table 4 below. I used three regression models to test the above relationships: mixed regression model, fixed-effect model, and random effect model. The fixed-effect model was selected in the mixed model and the fixed-effect model by the $\mathrm{F}$ test, the random-effect model was selected in the mixed model and the random-effect model by the BP test, and finally, the fixed effect model was determined in the fixed effect model and the random effect model by the Hausman test.

The results show that the coefficient of corporate social responsibility risk (CSR Risk) is negative (-0.072) and significant at the level of $1 \%$, indicating that the greater the corporate social responsibility risk, the lower the institutional investor's shareholding ratio, which indicates that institutional investors are concerned about CSR Risk when making decisions. This is mainly because of the pressure of social public opinion and negative media reports that make companies "exposed" to social responsibility risk, damage the reputation of the company (Core et al., 2008; Christensen, 2015), and affect the sustainability and long-term earnings value. In order to avoid market value damage caused by corporate social responsibility risk, institutional investors will reduce or even refuse to invest in companies with higher social responsibility risk when making investment decisions in order to reduce their investment risks.

\subsubsection{Degree of Marketization, CSR Risk and Institutional Investors}

Further, I tried to understand the impact of different degrees of marketization on social responsibility risk and the institutional investor's shareholding relationship. I divided the sample into two sub-samples of the High Market Level and Low Market Level according to the median of the Marketization Index of each region, and performed regression analysis according to model (1). The results are shown in Table 5 below.

The results show that in the samples with high degree of marketization, the coefficient of corporate social responsibility risk (CSR Risk) is significantly negative. However, in the sample of companies with low degree of marketization, although the coefficient of social responsibility risk (CSR Risk) is also negative, but It is not significant, which indicates that in regions with a high degree of marketization, institutional investors' holdings of shares are more significantly affected by corporate social responsibility risk. The possible explanation is that, on the one hand, in areas with rapid marketization, external attention pressure and 
Table 4. CSR risk and institutional investors.

\begin{tabular}{|c|c|c|c|}
\hline & \multicolumn{3}{|c|}{ INS } \\
\hline & Mixed regression model & Fixed effect model & Random effects model \\
\hline \multirow[t]{2}{*}{ CSR Risk } & $-0.072^{\star * \star}$ & $-0.072^{\star \star \star}$ & $-0.069^{\star * *}$ \\
\hline & $(-2.69)$ & $(-2.88)$ & $(-2.77)$ \\
\hline \multirow[t]{2}{*}{ ROA } & $13.084^{*}$ & $13.084^{*}$ & $19.609^{* * *}$ \\
\hline & $(1.69)$ & $(1.81)$ & $(2.70)$ \\
\hline \multirow[t]{2}{*}{ SIZE } & $-3.411^{* * *}$ & $-3.411^{\star * *}$ & $-3.694^{* * *}$ \\
\hline & $(-3.82)$ & $(-4.09)$ & $(-4.82)$ \\
\hline \multirow[t]{2}{*}{ State } & -0.141 & -0.141 & $4.981^{\star * *}$ \\
\hline & $(-0.06)$ & $(-0.06)$ & $(3.84)$ \\
\hline \multirow[t]{2}{*}{ LEV } & $19.687^{* * *}$ & $19.687^{\star * *}$ & $23.246^{\star * *}$ \\
\hline & $(4.77)$ & $(5.11)$ & $(7.76)$ \\
\hline \multirow[t]{2}{*}{ TRSHARE } & $10.938^{\star * *}$ & $10.938^{\star * *}$ & $9.874^{* * *}$ \\
\hline & $(8.37)$ & $(8.96)$ & $(10.58)$ \\
\hline \multirow[t]{2}{*}{ TOP } & $0.290^{\star * *}$ & $0.290^{\star * *}$ & $0.367^{* * *}$ \\
\hline & $(4.50)$ & $(4.82)$ & $(10.93)$ \\
\hline \multirow[t]{2}{*}{ BPS } & $2.453^{\star * *}$ & $2.453^{\star * *}$ & $2.556^{\star * *}$ \\
\hline & $(8.61)$ & $(9.22)$ & $(10.92)$ \\
\hline \multirow[t]{2}{*}{ TAMVB } & $-30.075^{\star * *}$ & $-30.075^{\star * *}$ & $-27.534^{\star * *}$ \\
\hline & $(-10.68)$ & $(-11.44)$ & $(-11.73)$ \\
\hline \multirow[t]{2}{*}{ Mortgage } & -0.186 & -0.186 & 0.754 \\
\hline & $(-0.08)$ & $(-0.09)$ & $(0.40)$ \\
\hline \multirow[t]{2}{*}{ IDB } & -10.399 & -10.399 & $-13.767^{\star *}$ \\
\hline & $(-1.16)$ & $(-1.24)$ & $(-1.96)$ \\
\hline \multirow[t]{2}{*}{ GCFO } & 0.033 & 0.033 & 0.022 \\
\hline & $(0.81)$ & $(0.87)$ & $(0.56)$ \\
\hline \multirow[t]{2}{*}{ SC } & 7.432 & 7.432 & $13.893^{\star *}$ \\
\hline & $(1.15)$ & $(1.23)$ & $(2.43)$ \\
\hline \multirow[t]{2}{*}{ VOL } & $-4.977^{* * *}$ & $-4.977^{\star * *}$ & $-5.347^{* * *}$ \\
\hline & $(-15.75)$ & $(-16.87)$ & $(-19.46)$ \\
\hline \multirow[t]{2}{*}{ JNN } & $680.164^{* * *}$ & $680.164^{\star * *}$ & 52.276 \\
\hline & $(4.31)$ & $(4.62)$ & $(0.44)$ \\
\hline \multirow[t]{2}{*}{ Growth } & -0.223 & -0.223 & -0.463 \\
\hline & $(-0.61)$ & $(-0.66)$ & $(-1.34)$ \\
\hline \multirow[t]{2}{*}{ ROWC } & -0.005 & -0.005 & -0.006 \\
\hline & $(-0.60)$ & $(-0.64)$ & $(-0.74)$ \\
\hline \multirow[t]{2}{*}{ Constant } & $-122.397^{* * *}$ & $-104.317^{* * *}$ & $-84.630^{* * *}$ \\
\hline & $(-4.22)$ & $(-4.33)$ & $(-7.05)$ \\
\hline Stkcd FE/Year FE & control & control & control \\
\hline Observations & 3569 & 3569 & 3569 \\
\hline Adjusted $\mathrm{R}^{2}$ & 0.735 & 0.410 & 0.404 \\
\hline
\end{tabular}


Table 5. Degree of marketization, CSR risk and institutional investors.

\begin{tabular}{|c|c|c|c|}
\hline & \multicolumn{3}{|c|}{ INS } \\
\hline & Full Sample & High Market level & Low Market level \\
\hline \multirow[t]{2}{*}{ CSR Risk } & $-0.072^{\star * *}$ & $-0.101^{\star * *}$ & -0.039 \\
\hline & $(-2.88)$ & $(-2.80)$ & $(-1.03)$ \\
\hline \multirow[t]{2}{*}{ ROA } & $13.084^{*}$ & 12.622 & 6.666 \\
\hline & $(1.81)$ & $(1.09)$ & $(0.70)$ \\
\hline \multirow[t]{2}{*}{ SIZE } & $-3.411^{\star * *}$ & $-2.956^{\star *}$ & $-3.479^{\star * *}$ \\
\hline & $(-4.09)$ & $(-2.51)$ & $(-2.85)$ \\
\hline \multirow[t]{2}{*}{ State } & -0.141 & -0.364 & 0.203 \\
\hline & $(-0.06)$ & $(-0.07)$ & $(0.08)$ \\
\hline \multirow[t]{2}{*}{ LEV } & $19.687^{* * *}$ & $17.257^{\star * *}$ & $22.563^{* * *}$ \\
\hline & $(5.11)$ & $(3.03)$ & $(4.21)$ \\
\hline \multirow[t]{2}{*}{ TRSHARE } & $10.938^{* * *}$ & $10.677^{* * *}$ & $12.446^{* * *}$ \\
\hline & $(8.96)$ & $(6.12)$ & $(6.75)$ \\
\hline \multirow[t]{2}{*}{ TOP } & $0.290^{* * *}$ & $0.361^{\star \star \star}$ & $0.213^{* * *}$ \\
\hline & $(4.82)$ & $(3.61)$ & $(2.72)$ \\
\hline \multirow[t]{2}{*}{ BPS } & $2.453^{* * *}$ & $2.735^{\star * *}$ & $2.119^{* * *}$ \\
\hline & $(9.22)$ & $(7.09)$ & $(5.44)$ \\
\hline \multirow[t]{2}{*}{ TAMVB } & $-30.075^{\star * *}$ & $-28.262^{\star * *}$ & $-33.744^{* * *}$ \\
\hline & $(-11.44)$ & $(-7.38)$ & $(-8.49)$ \\
\hline \multirow[t]{2}{*}{ Mortgage } & -0.186 & -3.664 & 2.196 \\
\hline & $(-0.09)$ & $(-1.15)$ & $(0.81)$ \\
\hline \multirow[t]{2}{*}{ IDB } & -10.399 & -10.514 & -11.716 \\
\hline & $(-1.24)$ & $(-0.86)$ & $(-1.21)$ \\
\hline \multirow[t]{2}{*}{ GCFO } & 0.033 & 0.037 & -0.021 \\
\hline & $(0.87)$ & $(0.55)$ & $(-0.47)$ \\
\hline \multirow[t]{2}{*}{ SC } & 7.432 & -1.299 & $17.195^{\star *}$ \\
\hline & $(1.23)$ & $(-0.16)$ & $(2.03)$ \\
\hline \multirow[t]{2}{*}{ VOL } & $-4.977^{\star * *}$ & $-5.338^{* * *}$ & $-4.551^{\star * *}$ \\
\hline & $(-16.87)$ & $(-11.48)$ & $(-11.71)$ \\
\hline \multirow[t]{2}{*}{ JNN } & $680.164^{\star * *}$ & $746.483^{* \star *}$ & $762.409^{* * *}$ \\
\hline & $(4.62)$ & $(3.76)$ & $(3.16)$ \\
\hline \multirow[t]{2}{*}{ Growth } & -0.223 & -0.137 & -0.005 \\
\hline & $(-0.66)$ & $(-0.24)$ & $(-0.01)$ \\
\hline \multirow{2}{*}{ ROWC } & -0.005 & -0.014 & 0.003 \\
\hline & $(-0.64)$ & $(-1.09)$ & $(0.22)$ \\
\hline \multirow[t]{2}{*}{ Constant } & $-104.317^{* * *}$ & $-110.397^{* * *}$ & $-129.769^{* * *}$ \\
\hline & $(-4.33)$ & $(-3.28)$ & $(-3.63)$ \\
\hline Stkcd FE/Year FE & control & control & control \\
\hline Observations & 3569 & 3569 & 3569 \\
\hline Adjusted $\mathrm{R}^{2}$ & 0.410 & 0.388 & 0.449 \\
\hline
\end{tabular}


regulatory systems make corporate social responsibility disclosure quality higher, and institutional investors can assess corporate social responsibility risk at a lower cost To make investment decisions. On the other hand, a relatively complete legal environment reduces the probability of rent-seeking behavior in the media and improves the transparency and authenticity of corporate social responsibility information. Relatively speaking, in regions with slower marketization, institutional investors have less willingness to invest.

\subsubsection{Property Right, CSR Risk and Institutional Investors}

Due to China's special institutional environment, the differences in the nature of property rights have been a hot topic for domestic scholars. In order to investigate whether the impact of corporate social responsibility risk on institutional investors will have different performance in different property rights, this article divides the sample into state-owned enterprise groups (SOEs) and non-stateowned enterprise groups (Non-SOEs), and follows the model (1) The results of group inspection are shown in Table 6.

Regression results show that in the sample of state-owned enterprises, the coefficient of corporate social responsibility risk (CSR Risk) is negative and significant at the level of $5 \%$. However, in the sample of non-state-owned enterprises, although the coefficient of social responsibility risk (CSR Risk) is also It is negative, but not significant, which shows that the negative impact of corporate social responsibility risk on institutional investor's shareholding is more significant in non-state-owned enterprises. This is because, on the one hand, stateowned enterprises and the government have an inherently close relationship. State-owned enterprises often need to assume macro-control functions such as maintaining social stability and stabilizing prices. When state-owned enterprises face the pressure of negative public opinion due to the social responsibility risk, the government or state-owned shareholders will use media control and other means to regulate public opinion. On the other hand, close government-enterprise relations give state-owned enterprises an inherent advantage in accessing social resources. Even in the face of social responsibility risk, the negative impact of state-owned enterprises is often smaller than that of non-state-owned enterprises.

\subsubsection{Business Performance, CSR Risk and Institutional Investors}

Given that "Although the emergence of social responsibility standards may affect the investment activities of institutional investors, these standards may still be subordinate to economic standards" (Coffey and Fryxell, 1991), I suspect that the relationship between corporate social responsibility risk and institutional ownership may vary greatly depending on the company's financial performance. Therefore, I divided the sample into high-performance groups (High ROA level) and Low ROA level, and the regression analysis was performed according to model (1). The results are shown in Table 7. 
Table 6. Property Right, CSR risk and institutional investors.

\begin{tabular}{|c|c|c|c|}
\hline & \multicolumn{3}{|c|}{ INS } \\
\hline & Full Sample & SOEs & Non-SOEs \\
\hline \multirow[t]{2}{*}{ CSR Risk } & $-0.072^{\star * *}$ & -0.041 & $-0.083^{* *}$ \\
\hline & $(-2.88)$ & $(-1.38)$ & $(-2.08)$ \\
\hline \multirow[t]{2}{*}{ ROA } & $13.084^{*}$ & $22.329^{* *}$ & 6.300 \\
\hline & $(1.81)$ & $(2.58)$ & $(0.57)$ \\
\hline \multirow[t]{2}{*}{ SIZE } & $-3.411^{\star \star \star}$ & $-2.724^{\star \star}$ & -2.026 \\
\hline & $(-4.09)$ & $(-2.57)$ & $(-1.51)$ \\
\hline \multirow[t]{2}{*}{ State } & -0.141 & & \\
\hline & $(-0.06)$ & & \\
\hline \multirow[t]{2}{*}{ LEV } & $19.687^{\star * *}$ & $22.861^{\star * *}$ & $22.867^{\star * *}$ \\
\hline & $(5.11)$ & $(4.30)$ & $(4.52)$ \\
\hline \multirow[t]{2}{*}{ TRSHARE } & $10.938^{* * *}$ & $15.299^{* * *}$ & $9.368^{* * *}$ \\
\hline & $(8.96)$ & $(9.88)$ & $(5.12)$ \\
\hline \multirow[t]{2}{*}{ TOP } & $0.290^{\star * *}$ & $0.277^{\star * *}$ & 0.154 \\
\hline & $(4.82)$ & $(3.69)$ & $(1.43)$ \\
\hline \multirow[t]{2}{*}{ BPS } & $2.453^{* * *}$ & $2.012^{\star * *}$ & $3.204^{* * *}$ \\
\hline & $(9.22)$ & $(6.60)$ & $(7.09)$ \\
\hline \multirow[t]{2}{*}{ TAMVB } & $-30.075^{\star * \star}$ & $-31.116^{* * *}$ & $-40.165^{\star * *}$ \\
\hline & $(-11.44)$ & $(-9.39)$ & $(-8.76)$ \\
\hline \multirow[t]{2}{*}{ Mortgage } & -0.186 & 0.650 & -2.966 \\
\hline & $(-0.09)$ & $(0.28)$ & $(-0.78)$ \\
\hline \multirow[t]{2}{*}{ IDB } & -10.399 & -6.882 & $-23.903^{*}$ \\
\hline & $(-1.24)$ & $(-0.73)$ & $(-1.77)$ \\
\hline \multirow[t]{2}{*}{ GCFO } & 0.033 & 0.002 & 0.070 \\
\hline & $(0.87)$ & $(0.04)$ & $(0.99)$ \\
\hline \multirow[t]{2}{*}{ SC } & 7.432 & 5.118 & 11.584 \\
\hline & $(1.23)$ & $(0.62)$ & $(1.42)$ \\
\hline \multirow[t]{2}{*}{ VOL } & $-4.977^{\star * *}$ & $-5.261^{* * *}$ & $-4.570^{\star * \star}$ \\
\hline & $(-16.87)$ & $(-12.57)$ & $(-12.03)$ \\
\hline \multirow[t]{2}{*}{ JNN } & $680.164^{\star * *}$ & 684.446 & $417.652^{\star * *}$ \\
\hline & $(4.62)$ & $(1.27)$ & $(2.75)$ \\
\hline \multirow[t]{2}{*}{ Growth } & -0.223 & 0.123 & -0.222 \\
\hline & $(-0.66)$ & $(0.27)$ & $(-0.42)$ \\
\hline \multirow[t]{2}{*}{ ROWC } & -0.005 & 0.002 & -0.018 \\
\hline & $(-0.64)$ & $(0.17)$ & $(-1.35)$ \\
\hline \multirow[t]{2}{*}{ Constant } & $-104.317^{\star \star *}$ & $-203.609^{* * *}$ & $-97.726^{\star * *}$ \\
\hline & $(-4.33)$ & $(-6.28)$ & $(-2.79)$ \\
\hline Stkcd FE/Year FE & control & control & control \\
\hline Observations & 3569 & 3569 & 3569 \\
\hline Adjusted $\mathrm{R}^{2}$ & 0.410 & 0.471 & 0.375 \\
\hline
\end{tabular}


Table 7. Business performance, CSR risk and institutional investors.

\begin{tabular}{|c|c|c|c|}
\hline & \multicolumn{3}{|c|}{ INS } \\
\hline & Full Sample & High ROA level & Low ROA level \\
\hline \multirow[t]{2}{*}{ CSR Risk } & $-0.072^{* * *}$ & $-0.077^{\star \star}$ & -0.045 \\
\hline & $(-2.88)$ & $(-2.06)$ & $(-1.49)$ \\
\hline \multirow[t]{2}{*}{ ROA } & $13.084^{*}$ & -1.538 & 14.270 \\
\hline & $(1.81)$ & $(-0.10)$ & $(1.44)$ \\
\hline \multirow[t]{2}{*}{ SIZE } & $-3.411^{\star * *}$ & $-4.329^{\star * \star}$ & $-2.633^{* *}$ \\
\hline & $(-4.09)$ & $(-3.73)$ & $(-2.18)$ \\
\hline \multirow[t]{2}{*}{ State } & -0.141 & 0.011 & -1.797 \\
\hline & $(-0.06)$ & $(0.00)$ & $(-0.81)$ \\
\hline \multirow[t]{2}{*}{ LEV } & $19.687^{\star * *}$ & $23.310^{* * *}$ & $17.462^{\star * *}$ \\
\hline & $(5.11)$ & $(3.53)$ & $(3.62)$ \\
\hline \multirow[t]{2}{*}{ TRSHARE } & $10.938^{\star * *}$ & $8.396^{* * *}$ & $15.284^{\star * *}$ \\
\hline & $(8.96)$ & $(4.93)$ & $(7.91)$ \\
\hline \multirow[t]{2}{*}{ TOP } & $0.290^{* * *}$ & $0.201^{* *}$ & $0.347^{* * *}$ \\
\hline & $(4.82)$ & $(2.23)$ & $(3.78)$ \\
\hline \multirow[t]{2}{*}{ BPS } & $2.453^{* * *}$ & $2.095^{\star * *}$ & $3.022^{* * *}$ \\
\hline & $(9.22)$ & (6.69) & $(5.77)$ \\
\hline \multirow[t]{2}{*}{ TAMVB } & $-30.075^{\star * *}$ & $-34.713^{* * *}$ & $-28.551^{\star * *}$ \\
\hline & $(-11.44)$ & $(-8.50)$ & $(-7.74)$ \\
\hline \multirow[t]{2}{*}{ Mortgage } & -0.186 & 2.371 & -1.570 \\
\hline & $(-0.09)$ & $(0.76)$ & $(-0.53)$ \\
\hline \multirow[t]{2}{*}{ IDB } & -10.399 & -7.147 & -14.497 \\
\hline & $(-1.24)$ & $(-0.53)$ & $(-1.54)$ \\
\hline \multirow[t]{2}{*}{ GCFO } & 0.033 & $0.136^{* *}$ & -0.010 \\
\hline & $(0.87)$ & $(2.00)$ & $(-0.23)$ \\
\hline \multirow[t]{2}{*}{ SC } & 7.432 & 9.215 & $21.690^{*}$ \\
\hline & $(1.23)$ & $(1.33)$ & $(1.91)$ \\
\hline \multirow[t]{2}{*}{ VOL } & $-4.977^{\star * *}$ & $-5.684^{* * *}$ & $-3.965^{\star * *}$ \\
\hline & $(-16.87)$ & $(-12.37)$ & $(-9.89)$ \\
\hline \multirow[t]{2}{*}{ JNN } & $680.164^{* * *}$ & $518.372^{* * *}$ & $938.619^{* * *}$ \\
\hline & $(4.62)$ & $(2.79)$ & $(3.28)$ \\
\hline \multirow[t]{2}{*}{ Growth } & -0.223 & -0.284 & $-0.882^{\star * *}$ \\
\hline & $(-0.66)$ & $(-0.51)$ & $(-2.67)$ \\
\hline \multirow[t]{2}{*}{ ROWC } & -0.005 & 0.001 & -0.007 \\
\hline & $(-0.64)$ & $(0.06)$ & $(-0.52)$ \\
\hline \multirow[t]{2}{*}{ Constant } & $-104.317^{* * \star}$ & -28.235 & $-211.678^{\star * *}$ \\
\hline & $(-4.33)$ & $(-0.86)$ & $(-4.89)$ \\
\hline Stkcd FE/Year FE & control & control & control \\
\hline Observations & 3569 & 3569 & 3569 \\
\hline Adjusted $\mathrm{R}^{2}$ & 0.410 & 0.344 & 0.460 \\
\hline
\end{tabular}


The results show that in the high-performance samples, the coefficient of corporate social responsibility risk (CSR Risk) is significantly negative, but in the low-performance company sample, although the coefficient of social responsibility risk (CSR Risk) is also negative, it is not significant. The possible reason is that, on the one hand, the screening of corporate social responsibility risk by institutional investors is more of a "negative screening" (Mao et al., 2012). In order to obtain a higher return on investment, institutional investors often do not take corporate social responsibility risk as the primary consideration when making decisions, but rather give priority to companies considering corporate profit data and favorable policies. Therefore, they will first screen the companies with better financial performance from the perspective of financial feasibility, and the companies with low performance are often excluded from consideration in the first round of screening by institutional investors. On the other hand, companies with better financial performance generally receive more market attention and higher expectations (Shen, 2007), which makes these companies subject to more media reports and public condemnation when they are facing social responsibility risk. Eventually damage the long-term value of the company (Byun and Oh, 2018) and affect investors' willingness to invest. Therefore, when high-performance companies face social responsibility risk, institutional investors may choose to reduce or abandon their investment in the company due to investment risk considerations, and institutional investors often do not invest in companies with poor financial performance.

\subsection{Further Analysis}

Further, we are trying to understand why corporate social responsibility risk affects the shareholding behavior of institutional investors. Many scholars' research has proved that the quality of corporate social responsibility will affect corporate performance (McPeak \& Tooley, 2008; Zhang et al., 2014). Corporate social responsibility risk will not only damage the reputation of the company (Core et al., 2008; Christensen, 2015), but also reduce the financial and non-financial performance of the company (Simpson \& Kohers, 2002), thus making the company Suffering a corresponding loss of market value (Karpoff et al., 2005). At the same time, corporate social responsibility risk can also damage the trust of governments, financial institutions, and investors in companies (Goss and Roberts, 2011), affecting companies' access to government financial subsidies and income tax benefits ( $\mathrm{Li}$ and $\mathrm{Lu}, 2015)$, Increasing the difficulty and cost of corporate financing (Cheng et al., 2014), affecting the continued operation of the enterprise. Therefore, from this perspective, the higher the corporate social responsibility risk, the worse the company's earnings sustainability and corporate value may be (Byun and Oh, 2018), which will affect institutional investors' shareholding decisions. Therefore, in order to explore the impact path and internal mechanism of corporate social responsibility risk on institutional investor's shareholding behavior, this paper constructs the following models. 


$$
\begin{aligned}
& \mathrm{CROA}_{i, t+1}=\alpha_{0}+\alpha_{1} \mathrm{CSRRisk}_{i, t}+\alpha_{2} \mathrm{CSRRisk}_{i, t} * \mathrm{CROA}_{i, t}+\alpha_{3} \mathrm{CROA}_{i, t} \\
& +\alpha_{4} \mathrm{SIZE}_{i, t}+\alpha_{5} \mathrm{LEV}_{i, t}+\alpha_{6} \mathrm{State}_{i, t}+\alpha_{7} \mathrm{ROA}_{i, t}+\alpha_{8} \mathrm{VOL}_{i, t} \\
& +\alpha_{9} \mathrm{TOP}_{i, t}+\alpha_{10} \mathrm{BPS}_{i, t}+\alpha_{11} \mathrm{EXCP}_{i, t}+\alpha_{12} \mathrm{IDB}_{i, t}+\alpha_{13} \mathrm{TAMVB}_{i, t} \\
& +\alpha_{14} \text { Mortgage }_{i, t}+\alpha_{15} \mathrm{SC}_{i, t}+\alpha_{16} \text { WCLRat }_{i, t}+\text { Stkcdeffect } \\
& + \text { Yeareffect }+\varepsilon_{i, t} \\
& \text { TobinQ }=\alpha_{0}+\alpha_{1} \text { CSRRisk }_{t}+\alpha_{2} \text { SIZE }+\alpha_{3} \mathrm{LEV}+\alpha_{4} \text { State }+\alpha_{5} \mathrm{ROA}+\alpha_{6} \mathrm{VOL} \\
& +\alpha_{7} \mathrm{TOP}+\alpha_{8} \mathrm{BPS}+\alpha_{9} \mathrm{EXCP}+\alpha_{10} \mathrm{IDB}+\alpha_{11} \mathrm{TAMVB}+\alpha_{12} \mathrm{SC} \\
& +\alpha_{13} \text { Mortgage }+\alpha_{14} \text { WCLRat }+ \text { Stkcdeffect }+ \text { Yeareffect }+\varepsilon
\end{aligned}
$$

In model (2), $\mathrm{CROA}_{i, t+1}$ and $\mathrm{CROA}_{i, t}$ are the main business surplus in period $\mathrm{t}$ +1 and the main business surplus in period $t$, respectively, where the main business surplus is equal to the main business profit divided by the total assets. In model (3), TobinQ is the value of the enterprise. See Table 2 for definitions of other variables.

In order to avoid multicollinearity between the interaction terms and the main independent variables, the cross-product terms (CSR Risk ${ }_{i, t}$ and $\mathrm{CROA}_{i, t}$ ) are decentralized in the model (2). This paper conducts regression analysis according to model (2) and model (3), and uses three regression models to test the above relationships, which are mixed regression model, fixed effect model and random effect model. The results are shown in Table 8.

In the study of social responsibility risk and the sustainability of corporate earnings, the regression results show that the coefficient of the crossover term $\left(\mathrm{CSR}\right.$ Risk $\left.{ }^{\star} \mathrm{CROA}_{i, t}\right)$ is negative and significant at the level of $1 \%$, indicating that corporate social responsibility risk will indeed be negative Affects corporate earnings sustainability. In the study of social responsibility risk and corporate value, the results show that the coefficient of corporate social responsibility risk (CSR Risk) is significantly negative, meaning that corporate social responsibility risk will also negatively affect the value of the enterprise. This is mainly because corporate social responsibility risk will affect the company's reputation and social identity, and reduce the company's operating performance; at the same time, social responsibility risk will also damage the confidence of the government, financial institutions and investors in the company, and increase the difficulty of the company in obtaining social resources, Which affects the sustainability and long-term value of the company's earnings, and ultimately affects the investment decisions of institutional investors.

\subsection{Robustness Analysis}

\subsubsection{Endogenous Problem}

One issue that this article has to face squarely is that there may be interactions between corporate social responsibility risk and institutional investor ownership. This also means that the corporate social responsibility risk and the institutional investor's shareholding ratio are mutually causal to a certain extent, which may lead to serious endogenous problems in the model. 
Table 8. Corporate social responsibility risk and earnings sustainability \& corporate value.

\begin{tabular}{|c|c|c|c|c|c|c|}
\hline & \multicolumn{3}{|c|}{$\mathrm{CROA}_{i, t+1}$} & \multicolumn{3}{|c|}{ TobinQ } \\
\hline & Mixed regression & Fixed effect & Random effect & Mixed regression & Fixed effect & Random effect \\
\hline \multirow[t]{2}{*}{ CSR Risk } & $0.0003^{* * *}$ & $0.0003^{\star * *}$ & $0.0003^{* * *}$ & $-0.002^{\star}$ & $-0.002^{\star *}$ & $-0.002^{\star}$ \\
\hline & $(2.72)$ & $(2.92)$ & $(3.02)$ & $(-1.86)$ & $(-1.99)$ & $(-1.69)$ \\
\hline \multirow[t]{2}{*}{ CSR Risk ${ }^{*} \mathrm{CROA}_{\mathrm{i}, \mathrm{t}}$} & $-0.002^{\star * *}$ & $-0.002^{* * *}$ & $-0.002^{* * *}$ & & & \\
\hline & $(-2.74)$ & $(-2.94)$ & $(-2.68)$ & & & \\
\hline \multirow[t]{2}{*}{ CROA } & $0.597^{* * *}$ & $0.597^{* * *}$ & $0.884^{* * *}$ & & & \\
\hline & $(17.75)$ & (19.04) & $(37.87)$ & & & \\
\hline \multirow[t]{2}{*}{$\mathrm{ROA}$} & $-0.199^{* * *}$ & $-0.199^{* * *}$ & $-0.237^{\star * *}$ & $2.492^{\star * *}$ & $2.492^{\star * *}$ & $2.254^{\star \star \star}$ \\
\hline & $(-5.28)$ & $(-5.66)$ & $(-8.29)$ & $(4.58)$ & $(4.91)$ & $(4.79)$ \\
\hline \multirow[t]{2}{*}{ SIZE } & $-0.010^{* * *}$ & $-0.010^{* * *}$ & -0.0005 & $-0.175^{* * *}$ & $-0.175^{* * *}$ & $-0.066^{* * *}$ \\
\hline & $(-3.53)$ & $(-3.79)$ & $(-0.44)$ & $(-3.95)$ & $(-4.23)$ & $(-2.65)$ \\
\hline \multirow[t]{2}{*}{ State } & 0.004 & 0.004 & $-0.005^{* *}$ & $-0.493^{* * *}$ & $-0.493^{* * *}$ & $-0.108^{*}$ \\
\hline & $(0.58)$ & $(0.62)$ & $(-2.45)$ & $(-2.97)$ & $(-3.19)$ & $(-1.88)$ \\
\hline \multirow[t]{2}{*}{ LEV } & 0.002 & 0.002 & $-0.016^{\star *}$ & $0.454^{*}$ & $0.454^{*}$ & 0.156 \\
\hline & $(0.14)$ & $(0.15)$ & $(-2.44)$ & $(1.82)$ & $(1.95)$ & $(0.95)$ \\
\hline \multirow[t]{2}{*}{ TOP } & -0.0001 & -0.0001 & 0.0000 & -0.003 & -0.003 & 0.000 \\
\hline & $(-0.22)$ & $(-0.24)$ & $(0.49)$ & $(-0.64)$ & $(-0.69)$ & $(0.01)$ \\
\hline \multirow[t]{2}{*}{ BPS } & -0.001 & -0.001 & -0.000 & -0.013 & -0.013 & $-0.017^{\star *}$ \\
\hline & $(-0.84)$ & $(-0.90)$ & $(-0.30)$ & $(-1.37)$ & $(-1.47)$ & $(-2.43)$ \\
\hline \multirow[t]{2}{*}{ EXCP } & -0.004 & -0.004 & $0.004^{\star *}$ & -0.037 & -0.037 & -0.046 \\
\hline & $(-1.01)$ & $(-1.09)$ & $(2.51)$ & $(-0.69)$ & $(-0.74)$ & $(-1.34)$ \\
\hline \multirow[t]{2}{*}{ TAMVB } & $-0.061^{\star \star \star}$ & $-0.061^{\star \star *}$ & $-0.027^{\star * \star}$ & $-3.710^{* * \star}$ & $-3.710^{* * \star}$ & $-3.920^{\star * *}$ \\
\hline & $(-6.09)$ & $(-6.53)$ & $(-4.54)$ & $(-21.34)$ & $(-22.87)$ & $(-29.36)$ \\
\hline \multirow[t]{2}{*}{ Mortgage } & $0.017^{* *}$ & $0.017^{* *}$ & $0.007^{*}$ & 0.053 & 0.053 & 0.114 \\
\hline & $(2.34)$ & $(2.50)$ & $(1.77)$ & $(0.48)$ & $(0.52)$ & $(1.61)$ \\
\hline \multirow[t]{2}{*}{ WCLRat } & 0.00004 & $0.00004^{*}$ & $0.00005^{* * *}$ & -0.00004 & -0.00004 & 0.001 \\
\hline & $(1.57)$ & $(1.68)$ & $(2.79)$ & $(-0.06)$ & $(-0.07)$ & $(1.43)$ \\
\hline \multirow[t]{2}{*}{ IDB } & -0.012 & -0.012 & -0.010 & -0.173 & -0.173 & 0.119 \\
\hline & $(-0.49)$ & $(-0.52)$ & $(-0.68)$ & $(-0.35)$ & $(-0.38)$ & $(0.35)$ \\
\hline \multirow[t]{2}{*}{ SC } & $0.072^{*}$ & $0.072^{*}$ & $0.141^{\star * *}$ & -0.053 & -0.053 & 0.079 \\
\hline & $(1.81)$ & $(1.94)$ & $(4.49)$ & $(-0.09)$ & $(-0.10)$ & $(0.23)$ \\
\hline \multirow[t]{2}{*}{ VOL } & -0.001 & -0.001 & $-0.003^{\star * *}$ & -0.020 & -0.020 & $-0.030^{\star}$ \\
\hline & $(-1.09)$ & $(-1.17)$ & $(-4.38)$ & $(-1.06)$ & $(-1.14)$ & $(-1.75)$ \\
\hline \multirow[t]{2}{*}{ Constant } & $0.380^{* * *}$ & $0.355^{\star * *}$ & 0.015 & $9.847^{\star * *}$ & $9.270^{\star * *}$ & $6.818^{\star * *}$ \\
\hline & $(5.28)$ & $(5.98)$ & $(0.62)$ & $(8.02)$ & $(8.90)$ & (11.86) \\
\hline Stkcd FE/Year FE & control & control & control & control & control & control \\
\hline Observations & 3382 & 3382 & 3382 & 3414 & 3414 & 3414 \\
\hline Adjusted $\mathrm{R}^{2}$ & 0.853 & 0.396 & 0.372 & 0.769 & 0.570 & 0.568 \\
\hline
\end{tabular}




\section{1) Instrumental variable method}

In order to solve the endogenous problem between corporate social responsibility risk and institutional investor's shareholding ratio, I use the instrumental variable method. Previous research has shown that the performance of corporate social responsibility depends on the characteristics of the industry (Ioannou and Serafeim, 2012). At the same time, because government policies and laws and regulations have different requirements for corporate social responsibility at different stages, corporate social responsibility risk may vary with System changes over time (Ioannou and Serafeim, 2017). Therefore, I used the industry's annual average social responsibility risk (YCSR Risk) as an instrumental variable (Cheng et al., 2014; Harjoto et al., 2017). In fact, previous papers often used industry averages of the independent variables as instrumental variables (Hanlon et al., 2003).

Firstly, in this paper, through the Underidentification test, the $P$-value of the Kleibergen-Paap rk LM statistic is 0.0000 . The null hypothesis of "underidentification problem" is strongly rejected, that is, the instrumental variables are related to endogenous variables (Kleibergen and Paap, 2006). Secondly, the Weak identification test was used to further check whether the instrument variables were under-identified. The Kleibergen-Paap rk Wald F statistic (166.797) was greater than the Stock-Yogo weak ID test critical values at the level of $10 \%$ (19.93), so we reject the null hypothesis that "weak instrumental variables exist", and believe that instrumental variables have a strong correlation with endogenous variables; meanwhile, the regression results in the first stage of Table 9 show that the industry's annual average social responsibility risk The coefficient is significantly positive at the $1 \%$ level, indicating that the instrumental variable (YCSR Risk) has a better explanatory power for the endogenous explanatory variable (CSR Risk).

\section{2) Explanatory variable lags by one period}

In order to mitigate the endogenous nature of social responsibility risk and institutional investor holdings, we also take a lagging approach to explain variables, which has been widely used in China, most studies believe that the possible causal relationship between this independent variable and the dependent variable can be broken to some extent after lagging. Most studies believe that the possible causal relationship between this independent variable and the dependent variable can be broken to some extent after lag treatment. Based on this, I lag the corporate social responsibility risk (CSR Risk $\mathrm{i}_{\mathrm{i}, \mathrm{t}-1}$ ) and perform regression analysis according to model (1). The results show that the lagging period of the corporate social responsibility risk (CSR Risk $\mathrm{i}_{\mathrm{t}, \mathrm{t}-1}$ ) coefficient is significantly negative at the level of $5 \%$, which is consistent with the above empirical conclusions. This means that institutional investors will also pay attention to corporate social responsibility risk in the previous period, and the higher the social responsibility risk in the previous period, the lower the institutional investor's shareholding ratio. 
Table 9. CSR risk and institutional investors (2SLS).

\begin{tabular}{|c|c|c|}
\hline & \multicolumn{2}{|c|}{ INS } \\
\hline & First stage & second stage \\
\hline \multirow[t]{2}{*}{ YCSR Risk } & $0.923^{* * *}$ & \\
\hline & $(12.92)$ & \\
\hline \multirow[t]{2}{*}{ CSR Risk } & & $-0.630^{\star * *}$ \\
\hline & & $(-6.05)$ \\
\hline \multirow[t]{2}{*}{$\mathrm{ROA}$} & -2.659 & 10.197 \\
\hline & $(-0.54)$ & $(1.53)$ \\
\hline \multirow[t]{2}{*}{ SIZE } & -0.213 & $-3.381^{* * *}$ \\
\hline & $(-0.41)$ & $(-4.80)$ \\
\hline \multirow[t]{2}{*}{ State } & -0.402 & -0.263 \\
\hline & $(-0.30)$ & $(-0.14)$ \\
\hline \multirow[t]{2}{*}{ LEV } & -1.249 & $18.997^{\star * *}$ \\
\hline & $(-0.54)$ & $(6.01)$ \\
\hline \multirow[t]{2}{*}{ TRSHARE } & $1.803^{* * *}$ & $11.998^{\star * *}$ \\
\hline & $(3.36)$ & (13.38) \\
\hline \multirow[t]{2}{*}{ TOP } & 0.041 & $0.318^{\star * *}$ \\
\hline & $(1.27)$ & $(6.55)$ \\
\hline \multirow[t]{2}{*}{ BPS } & 0.234 & $2.598^{\star \star *}$ \\
\hline & $(1.49)$ & (11.85) \\
\hline \multirow[t]{2}{*}{ TAMVB } & -0.509 & $-31.319^{* * *}$ \\
\hline & $(-0.30)$ & $(-13.76)$ \\
\hline \multirow[t]{2}{*}{ Mortgage } & -0.283 & -0.835 \\
\hline & $(-0.15)$ & $(-0.37)$ \\
\hline \multirow[t]{2}{*}{ IDB } & 2.295 & -8.488 \\
\hline & $(0.45)$ & $(-1.26)$ \\
\hline \multirow[t]{2}{*}{ GCFO } & 0.010 & 0.041 \\
\hline & $(0.27)$ & $(0.98)$ \\
\hline \multirow[t]{2}{*}{ SC } & $9.513^{*}$ & $13.306^{*}$ \\
\hline & $(1.82)$ & $(1.80)$ \\
\hline \multirow[t]{2}{*}{ VOL } & 0.094 & $-4.965^{* * *}$ \\
\hline & $(0.49)$ & $(-17.57)$ \\
\hline \multirow[t]{2}{*}{ JNN } & $334.176^{* * *}$ & $851.581^{\star * *}$ \\
\hline & $(2.92)$ & (5.14) \\
\hline \multirow[t]{2}{*}{ Growth } & -0.432 & -0.449 \\
\hline & $(-1.60)$ & $(-1.18)$ \\
\hline \multirow[t]{2}{*}{ ROWC } & -0.011 & -0.010 \\
\hline & $(-1.56)$ & $(-1.25)$ \\
\hline
\end{tabular}


Continued

\begin{tabular}{ccc}
\hline Stkcd FE/Year FE & control & control \\
Observations & 3565 & 3565 \\
Adjusted $\mathrm{R}^{2}$ & 0.335 & 0.163 \\
\hline
\end{tabular}

Underidentification test: Kleibergen-Paap rk LM statistic $=109.317$; Chi-sq (2) $P$-value $=0.0000$; Kleibergen-Paap rk LM statistic: Kleibergen-Paap rk Wald F statistic $=166.797>10 \%$ maximal IV size (19.93); Hansen J statistic: overidentification test of all instruments $=0.000$.

\subsubsection{Robustness Test}

Firstly, replacing the explanatory variable indicators. Using the change in the institutional investor's shareholding ratio (INSc) to replace the institutional investor's shareholding ratio in the original regression model, and re-estimate the model (1). The results are basically consistent with Tables 4-7.

Secondly, changing the control variable. For model (1) and model (4), I added executive compensation (EXCP) as a control variable based on the original control variables, and the top ten shareholders' shareholding ratio (H10) was used to measure the equity concentration of the company to replace the first shareholder's shareholding ratio (TOP) in the original model. Re-estimating the model (1), we find that the empirical results are also generally consistent with Tables 4-7. For model (2) and model (3), we replaced the shareholding ratio (TOP) of the largest shareholder in the original model with the shareholding ratio (H10) of the top ten shareholders, and re-estimated model (2), model (3), we find that the basic conclusions have not changed.

\section{Conclusion and Discussion}

\subsection{Research Conclusion}

Based on the Chinese capital market, this paper uses the RepRisk database to construct corporate social responsibility risk indicators, and examines the impact of corporate social responsibility risk on the investment behavior of institutional investors in China. The study found that there is a significant negative correlation between the institutional investor's shareholding and corporate social responsibility risk, which shows that institutional investors are concerned about corporate social responsibility risk when making investment decisions. And the above relationship is more significant in regions with higher levels of marketization, state-owned listed companies, and companies with better operating performance. In further analysis, we also found that corporate social responsibility risk will negatively affect earnings sustainability and corporate value, which means that investors investing in companies with higher social responsibility risk will reduce the investment value.

The research conclusions of this paper have the following three policy implications: First of all, this paper finds that institutional investors in China will consider the company's social responsibility and its risk performance when making decisions, so companies should pay attention to and prevent social responsibility risk. Secondly, although the rise and promotion of corporate social 
responsibility has caused investors to start paying attention to social responsibility and its risks, this is more a passive screening rather than business ethics progress brought by rapid economic development. Therefore, institutional investors should establish a positive sense of social responsibility and encourage enterprises to internalize social responsibility in their business activities. Third, in order to enable Chinese investors to objectively evaluate the performance of corporate social responsibility, relevant departments should speed up the formulation of corporate social responsibility information disclosure policies and regulations, and improve the role of media information transmission and public opinion supervision. Therefore, the corporate social responsibility behavior is placed under the "spotlight", so that enterprises with outstanding social responsibility performance can get the public's due recognition, and enterprises that have negative social responsibility behaviors get corresponding criticism and punishment.

\subsection{The Innovation and limitation}

Our research may have the following innovations: Firstly, China's current research on corporate social responsibility is mainly carried out from the positive impact of CSR, and our research is based on the negative impact of CSR Risk on companies, innovating the perspective of social responsibility research. Secondly, based on the objective situation of China's capital market, we grouped according to the degree of marketization, the nature of property rights and business performance, and explored the differences in the impact of CSR Risk and institutional investors in different situations. At the same time, the impact path of social responsibility risk on institutional investors' shareholding behavior is further studied, which is a useful supplement to relevant literature.

The limitations of this study are as follows. Firstly, it is about endogenous issues. Because CSR Risk and institutional investors' shareholding behavior will inevitably have endogenous problems. Although in this article, the introduction of instrumental variables for endogenous testing has been considered, only the industry average annual social responsibility risk (YCSR Risk) can be found as an instrumental variable to control endogenous problems. If more suitable instrumental variables can be found in subsequent research for further endogenous testing, the conclusions will be more rigorous and convincing. Secondly, it's about the sample data. Because China's social responsibility risk indicator measurement system has not yet been established, and the RepRisk database only measures social responsibility risk data for 530 listed companies in China, the amount of data in this article is relatively small. In the subsequent research, if more corporate social responsibility risk data can be found and further research is conducted, the results can be more rigorous.

\section{Conflicts of Interest}

The author declares no conflicts of interest regarding the publication of this paper. 


\section{References}

Arora, P., \& Dharwadkar, R. (2011). Corporate Governance and Corporate Social Responsibility (CSR): The Moderating Roles of Attainment Discrepancy and Organization Slack. Corporate Governance: An International Review, 19, 136-152. https://doi.org/10.1111/j.1467-8683.2010.00843.x

Becchetti, L., Ciciretti, R., Hasan, I., \& Kobeissi, N. (2012). Corporate Social Responsibility and Shareholder's Value. Journal of Business Research, 65, 1628-1635. https://doi.org/10.1016/j.jbusres.2011.10.022

Bednar, M. K., Boivie, S., \& Prince, N. R. (2013). Burr under the Saddle: How Media Coverage Influences Strategic Change. Organization Science, 24, 910-925. https://doi.org/10.1287/orsc.1120.0770

Boehmer, E., \& Kelley, E. K. (2009). Institutional Investors and the Informational Efficiency of Prices. The Review of Financial Studies, 22, 3563-3594. https://doi.org/10.1093/rfs/hhp028

Byun, S. K., \& Oh, J. M. (2018). Local Corporate Social Responsibility, Media Coverage, and Shareholder Value. Journal of Banking \& Finance, 87, 68-86. https://doi.org/10.1016/j.jbankfin.2017.09.010

Chan, K., Covrig, V., \& Ng, L. (2005). What Determines the Domestic Bias and Foreign Bias? Evidence from Mutual Fund Equity Allocations Worldwide. The Journal of Finance, 60, 1495-1534. https://doi.org/10.1111/j.1540-6261.2005.768_1.x

Chen, X., Harford, J., \& Li, K. (2007). Monitoring: Which Institutions Matter? Journal of Financial Economics, 86, 279-305. https://doi.org/10.1016/j.jfineco.2006.09.005

Cheng, B., Ioannou, I., \& Serafeim, G. (2014). Corporate Social Responsibility and Access to Finance. Strategic Management Journal, 35, 1-23. https://doi.org/10.1002/smj.2131

Christensen, D. M. (2015). Corporate Accountability Reporting and High-Profile Misconduct. The Accounting Review, 91, 377-399. https://doi.org/10.2308/accr-51200

Clarkson, P., Fang, X., Li, Y., \& Richardson, G. D. (2010). The Relevance of Environmental Disclosures for Investors and Other Stakeholder Groups: Are Such Disclosures Incrementally Informative? https://doi.org/10.2139/ssrn.1687475

Coffey, B. S., \& Fryxell, G. E. (1991). Institutional Ownership of Stock and Dimensions of Corporate Social Performance: An Empirical Examination. Journal of Business Ethics, 10, 437-444. https://doi.org/10.1007/BF00382826

Cooper, I., \& Kaplanis, E. (1994). Home Bias in Equity Portfolios, Inflation Hedging, and International Capital Market Equilibrium. The Review of Financial Studies, 7, 45-60. https://doi.org/10.1093/rfs/7.1.45

Core, J. E., Guay, W., \& Larcker, D. F. (2008). The Power of the Pen and Executive Compensation. Journal of Financial Economics, 88, 1-25. https://doi.org/10.1016/j.jfineco.2007.05.001

Cormier, D., Magnan, M., \& Van Velthoven, B. (2005). Environmental Disclosure Quality in Large German Companies: Economic Incentives, Public Pressures or Institutional Conditions? European Accounting Review, 14, 3-39. https://doi.org/10.1080/0963818042000339617

Cornett, M. M., Marcus, A. J., Saunders, A., \& Tehranian, H. (2007). The Impact of Institutional Ownership on Corporate Operating Performance. Journal of Banking \& Finance, 31, 1771-1794. https://doi.org/10.1016/j.jbankfin.2006.08.006

Cox, P., \& Wicks, P. G. (2011). Institutional Interest in Corporate Responsibility: Portfolio Evidence and Ethical Explanation. Journal of Business Ethics, 103, 143-165. https://doi.org/10.1007/s10551-011-0859-0 
Cox, P., Brammer, S., \& Millington, A. (2004). An Empirical Examination of Institutional Investor Preferences for Corporate Social Performance. Journal of Business Ethics, 52, 27-43. https://doi.org/10.1023/B:BUSI.0000033105.77051.9d

Dahlquist, M., \& Robertsson, G. (2001). Direct Foreign Ownership, Institutional Investors, and Firm Characteristics. Journal of Financial Economics, 59, 413-440. https://doi.org/10.1016/S0304-405X(00)00092-1

Dhaliwal, D. S., Li, O. Z., Tsang, A., \& Yang, Y. G. (2011). Voluntary Nonfinancial Disclosure and the Cost of Equity Capital: The Initiation of Corporate Social Responsibility Reporting. The Accounting Review, 86, 59-100. https://doi.org/10.2308/accr.00000005

Edmans, A. (2011). Does the Stock Market Fully Value Intangibles? Employee Satisfaction and Equity Prices. Journal of Financial Economics, 101, 621-640. https://doi.org/10.1016/j.jfineco.2011.03.021

Gompers, P. A., \& Metrick, A. (2001). Institutional Investors and Equity Prices. The Quarterly Journal of Economics, 116, 229-259. https://doi.org/10.1162/003355301556392

Goss, A., \& Roberts, G. S. (2011). The Impact of Corporate Social Responsibility on the Cost of Bank Loans. Journal of Banking \& Finance, 35, 1794-1810. https://doi.org/10.1016/j.jbankfin.2010.12.002

Graves, S. B., \& Waddock, S. A. (1994). Institutional Owners and Corporate Social Performance. Academy of Management Journal, 37, 1034-1046. https://doi.org/10.5465/256611

Grinblatt, M., \& Keloharju, M. (2001). How Distance, Language, and Culture Influence Stockholdings and Trades. The Journal of Finance, 56, 1053-1073. https://doi.org/10.1111/0022-1082.00355

Gurun, U. G., \& Butler, A. W. (2012). Don't Believe the Hype: Local Media Slant, Local Advertising, and Firm Value. The Journal of Finance, 67, 561-598. https://doi.org/10.1111/j.1540-6261.2012.01725.x

Hanlon, M., Rajgopal, S., \& Shevlin, T. (2003). Are Executive Stock Options Associated with Future Earnings? Journal of Accounting and Economics, 36, 3-43. https://doi.org/10.1016/j.jacceco.2003.10.008

Harjoto, M., Jo, H., \& Kim, Y. (2017). Is Institutional Ownership Related to Corporate Social Responsibility? The Nonlinear Relation and Its Implication for Stock Return Volatility. Journal of Business Ethics, 146, 77-109. https://doi.org/10.1007/s10551-015-2883-y

He, D., Tang, T., \& Chen, X. H. (2018). Institutional Environment,Institutional Investors ownership and Corporate Social Responsibility. Review of Investment Studies, 37, 122-146.

Hoq, M. Z., Saleh, M., Zubayer, M., \& Mahmud, K. T. (2010). The Effect of CSR Disclosure on Institutional Ownership. Pakistan Journal of Commerce and Social Sciences, 4, 22-39.

Ioannou, I., \& Serafeim, G. (2012). What Drives Corporate Social Performance? The Role of Nation-Level Institutions. Journal of International Business Studies, 43, 834-864. https://doi.org/10.1057/jibs.2012.26

Ioannou, I., \& Serafeim, G. (2017). The Consequences of Mandatory Corporate Sustainability Reporting. Harvard Business School Research Working Paper, (11-100).

Kang, J. K. (1997). Why Is There a Home Bias? An Analysis of Foreign Portfolio Equity Ownership in Japan. Journal of Financial Economics, 46, 3-28.

https://doi.org/10.1016/S0304-405X(97)00023-8 
Kangarluie, S. J., \& Bayazidi, A. (2011). Corporate Governance Mechanisms and Corporate Social Responsibility (CSR): Evidence from Iran. Australian Journal of Basic and Applied Sciences, 5, 1591-1598.

Karpoff, J. M., Lott Jr., J. R., \& Wehrly, E. W. (2005). The Reputational Penalties for Environmental Violations: Empirical Evidence. The Journal of Law and Economics, 48, 653-675. https://doi.org/10.1086/430806

Kleibergen, F., \& Paap, R. (2006). Generalized Reduced Rank Tests Using the Singular Value Decomposition. Journal of Econometrics, 133, 97-126. https://doi.org/10.1016/j.jeconom.2005.02.011

Lev, B., Petrovits, C., \& Radhakrishnan, S. (2010). Is Doing Good for You? How Corporate Charitable Contributions Enhance Revenue Growth. Strategic Management Journal, 31, 182-200. https://doi.org/10.1002/smj.810

Li, J., Lam, K., Qian, G., \& Fang, Y. (2006). The Effects of Institutional Ownership on Corporate Governance and Performance: An Empirical Assessment in Hong Kong. Management International Review, 46, 259-276. https://doi.org/10.1007/s11575-006-0047-0

Li, W. J., \& Lu, X. Y. (2015). Do Institutional Investors Care Firm Environmental Performance? Evidence from the Most Polluting Chinese Listed Firms. Journal of Financial Research, 12, 97-112.

Lin, S., Tian, S., \& Wu, E. (2013). Emerging Stars and Developed Neighbors: The Effects of Development Imbalance and Political Shocks on Mutual Fund Investments in China. Financial Management, 42, 339-371. https://doi.org/10.1111/j.1755-053X.2012.01206.x

Liu, Q. L., Li, H., Zhao, C., Liao, L. G., \& Chen, H. W. (2014). Negative Media Coverage, Litigation Risks and Audit Costs. Accounting Research, 6, 81-88.

Liu, Q. L., Li, W., \& Zhang, J. P. (2013). Negative Media Reports, Litigation Risks and Audit Contract Stability: A Study from the Perspective of External Governance. Management World, 11, 144-154.

Luo, X., \& Bhattacharya, C. B. (2009). The Debate over Doing Good: Corporate Social Performance, Strategic Marketing Levers, and Firm-Idiosyncratic Risk. Journal of Marketing, 73, 198-213. https://doi.org/10.1509/jmkg.73.6.198

Luo, X., Wang, H., Raithel, S., \& Zheng, Q. (2015). Corporate Social Performance, Analyst Stock Recommendations, and Firm Future Returns. Strategic Management Journal, 36, 123-136. https://doi.org/10.1002/smj.2219

Ma, H., \& Li, J. (2015). The Shunned-Stock Effect and the Error-in-Expectation Effect of Corporate Socially Responsible Investment-From the Perspective of Product Market Competition. China Industrial Economics, 3, 109-121.

Mao, L., Wang, Z. J., \& Wang, L. L. (2012). Institutional Investors Preferences, Screening and Corporate Social Performance. Journal of Management Science, 6, 21-33.

McPeak, C., \& Tooley, N. (2008). Do Corporate Social Responsibility Leaders Perform Better Financially? Journal of Global Business Issues, $2,1$.

Petersen, H. L., \& Vredenburg, H. (2009). Morals or Economics? Institutional Investor Preferences for Corporate Social Responsibility. Journal of Business Ethics, 90, 1. https://doi.org/10.1007/s10551-009-0030-3

Rozin, P., \& Royzman, E. B. (2001). Negativity Bias, Negativity Dominance, and Contagion. Personality and Social Psychology Review, 5, 296-320. https://doi.org/10.1207/S15327957PSPR0504_2

Shen, H. B., Xie, Y., \& Chen, Z. R. (2012). Environmental Protection, Corporate Social 
Responsibility and Its Market Response-Case Study Based on the Environmental Pollution Incident of Zijin Mining Group Co. China Industrial Economics, 1, 141-151.

Shen, H. T. (2007). Corporate Characteristics and Social Disclosure-Evidence from Listed Companies in China. Accounting Research, 3, 9-16.

Shi, J. L., \& Wang, J. L. (2014). Do Chinese Institutional Investors Really Stabilize the Market? Economic Research Journal, 12, 100-110.

Simpson, W. G., \& Kohers, T. (2002). The Link between Corporate Social and Financial Performance: Evidence from the Banking Industry. Journal of Business Ethics, 35, 97-109. https://doi.org/10.1023/A:1013082525900

Skinner, D. J., \& Srinivasan, S. (2012). Audit Quality and Auditor Reputation: Evidence from Japan. The Accounting Review, 87, 1737-1765. https://doi.org/10.2308/accr-50198

Song, Y., Shen, J., \& Fan, M. H. (2012). Do Geographical Features Affect the Holding Decision-Making of Institutional Investors? Empirical Evidence from China's Securities Market. Accounting Research, 7, 72-79.

Tetlock, P. C. (2007). Giving Content to Investor Sentiment: The Role of Media in the Stock Market. The Journal of Finance, 62, 1139-1168. https://doi.org/10.1111/j.1540-6261.2007.01232.x

Tian, S., Lin, S., \& Yu, Q. (2012). Investment Behaviour of Institutional Investors in Emerging Markets: Evidence from China. Journal of Financial Research, 8, 139-151.

Wang, Z., Xiao, M., \& Huang, Y. (2011). Research on the Impact of Corporate Social Responsibility on Institutional Shareholding. Finance \& Economy, 6, 66.

Xie, H. J., Jiang, D. C., \& Bao, Q. (2017). Lawsuits, Reputation and the Name Change Behavior of Chinese Listed Companies. Economic Research Journal, 52, 165-180.

Yang, M. Z. (2008). The Analysis of Institution Investo's Behavior in China Securities Market. Journal of Financial Research, 8, 133-144.

Ye, K. T., Zhang, R., \& Xu, H. P. (2010). Reputation, Institutional Environment and Debt Financing: Evidence from Private-Owned Listed Firms in China. Journal of Financial Research, 8, 171-183.

Zavyalova, A., Pfarrer, M. D., Reger, R. K., \& Shapiro, D. L. (2012). Managing the Message: The Effects of Firm Actions and Industry Spillovers on Media Coverage Following Wrongdoing. Academy of Management Journal, 55, 1079-1101. https://doi.org/10.5465/amj.2010.0608

Zhang, C., Lou, Z. K., \& Zhan, D. B. (2014). Political Connection, Financial Performance and Corporate Social Responsibility-Evidence From Listed Companies of the Chemical Industry in China. Management Review, 26, 130-139.

Zheng, Z. G. (2007). The Role of Corporate Governance in Extra-Legal Institutions: A Literature Review. Management World, 9, 136-147. 